\title{
Komunikasi Dalang Dalam Konsep Mandala Wiwaha Asep Sunandar Sunarya
}

Arthur S Nalan

Jurusan Teater, Sekolah Tinggi Seni Indonesia (STSI) Bandung

Jalan Buahbatu 212 Bandung 40265

\begin{abstract}
This study suggests the findings of field research on communication made by a puppeteer of Wayang Golek Purwa, Asep Sunandar Sunarya. This study is categorized into qualitative research with a phenomenological approach. The result of the study shows that Asep Sunandar Sunarya has performed his communication competencies as a communicative puppeteer. He has shown his creativity in building his characteristic through his performance. He has proven himself that he inherits Wayang Golek Purwa from his father and makes innovation in his performance. Communication competencies owned by Asep Sunandar Sunarya to the audience is based on his experience which is called the concept of Mandala Wiwaha. The concept of Mandala Wiwaha is a concept of technique, insight, message, and audience mastery. The concept of Mandala Wiwaha has made Asep Sunandar Sunarya a famous puppeteer who posses his own "popularity" compared to the other puppeteers. Through this concept Asep Sunandar Sunarya puts the audience as an important part every time he conducts his performance.
\end{abstract}

Keywords: Concept of Mandala Wiwaha, Communication of Puppeter

\section{PENDAHULUAN}

Dalang telah dipahami sebagai profesi yang memiliki kemampuan berkomunikasi dengan penontonnya secara menarik. Menarik karena menggunakan media wayang sebagai ekspresinya serta memiliki khalayak sasaran (target audience) yang beragam. Keberagaman penonton menjadikan dalang selalu mencoba memahami selera penontonnya supaya dapat melanjutkan tradisi yang diwarisinya. Melanjutkan tradisi yang diwarisinya tidak berarti statis tanpa perubahan di dalam pertunjukannya. Pertunjukan yang dinamis dan atraktif sangat dibutuhkan penonton dewasa ini ${ }^{1}$. Pertunjukan dina- mis dan atraktif dapat diartikan sebagai pertunjukan yang mencoba menawarkan hasil kreativitas berupa inovasi-inovasi baru yang jauh berbeda dari sebelumnya. Misalnya di dalam mengolah lakon dari pakem menjadi carangan yang benar-benar belum pernah dihadirkan oleh dalang wayang sebelumnya. Melahirkan bentuk-bentuk wayang kreasi dalam ukiran dan tokohnya. Memadukan potensi musik antara gamelan dengan alat musik perkusi lainnya. Penataan panggung dan tata pentas yang berbeda dari biasanya.

Inovasi yang dilakukan merupakan jawaban dari tantangan zaman yang dihadapi dewasa ini. Manusia yang yang mewarisi tradisinya secara turun temurun 
tidak dapat berhenti begitu saja, apalagi telah tumbuh sebagai pribadi yang ditokohkan oleh masyarakat. Masyarakat senantiasa menuntut yang baru dan yang tidak membosankan. Tuntutan itulah yang menjadi tantangan para dalang. Mengkutip pendapat Y.Boelaars dalam bukunya Kepribadian Indonesia Modern (1971: 9) menyatakan:

\footnotetext{
Manusia ternyata memiliki daya pengalaman, daya pengetahuan, daya kemauan, daya perasaan, daya ingatan, dan daya lamunan. Otak boleh diutamakan, hati boleh diberi prioritas, kemauan dapat didahulukan, akan tetapi semua daya itu diperalat untuk kepribadian manusia. Tanpa sadar manusia selalu memperhatikan apapun dengan melihat sekaligus rangka tempat dari apa yang diperhatikannya itu. Kenyataan ini mengakibatkan bahwa manusia merasa diri terlibat dan terikat kepada benda dan kepada sesama yang berada bersama dia. Namun justru sebagai manusia dia dapat menilai apa yang ditemukannya. Penilaian itu mendasari pilihannya di antara untung dan rugi, di antara baik dan jahat.
}

Dalang sebagai manusia yang memiliki daya-daya tersebut di atas telah memperlihatkan kreativitasnya dalam membangun pencitraan dirinya. Pencitraan dirinya sebagai seniman yang mampu berkomunikasi melalui wayang menjadi lebih komunikatif. Pengalaman menonton dalam konteks pembelajaran otodidak yang disebut guru panggung memberi banyak bekal baginya. Wayang sebagai media ekspresi kesenimanannya, biasanya mengandung unsur-unsur dasar kesatuan bentuk dan isi. Bentuk (form) merupakan keseluruhan bentuk pertunjukan, sedangkan isi (values) merupakan nilai-nilai dibalik bentuk. Adapun unsur-unsur kesatuan bentuk dan isi tersebut yaitu: Seni Cipta (konsepsi dan ciptaan baru); Seni Pentas (drama dan karawitan); Seni Kriya (pahat dan lukisan); Seni Ripta (sanggit dan kesusastraan); Seni Widya (filsafat dan pendidikan) (Solichin, 2003: 2)

Kesatuan bentuk dan isi memang seringkali mendapat tafsir kreatif dari sejumlah dalang. Tafsir kreatif dilakukan para dalang untuk menjawab tantangan zaman, terutama dinamika selera penonton. Dalang sebagai seniman umumnya tak mampu melakukan penolakan terhadap dinamika selera penonton ini, sebab penolakan berarti peluang untuk melanjutkan profesinya perlahan-lahan surut. Akhirnya dalang tersebut dapat saja berhenti menjadi dalang dan beralih profesi ke profesi lain. Dalang memang harus diakui seringkali berbicara dengan bahasa senimannya yang khas. Sebagaimana pendapat Primadi Tabrani (2006: xxiv-xxv) sebagai berikut:

Para seniman memang lebih suka berbicara tentang proses dan integrasi kreativitas dengan humanitas, tetapi pada umumnya mereka berbicara dengan bahasa senimannya yang khas, hingga dunia sains menilainya kurang begitu ilmiah, dan memang berbagai perumpamaan yang dikemukakan sering tidak benar secara ilmiah. Para eseis dan kritikus seni tak banyak bicara mengenai proses, mereka lebih bnayak bicara mengenai nilai-nilai.

Demikian pula dengan Dalang yang telah memiliki kekhasannya sendiri-sendiri. Kekhasan tersebut sesungguhnya identitas dari kesenimanannya. Kemampuan mengolah kelima unsur kesatuan bentuk dan isi menunjukan bahwa dalang tersebut memiliki kreativitas dan humanitas. Ditambahkan oleh Tabrani (2006: 39) dengan meminjam pendapat Jaquess Maritain yang mengatakan bahwa:

"Pada sumber tindakan kreatif, harus ada suatu proses intelek tertentu yang tidak dapat 
disebut berfikir logis (logical reason)... Pada pengalaman kreatif ini, dunia-luar (things) ditangkap dan dibawa ke 'dalam' (self) dan dunia-dalam (self) ditangkap di luar (things) dan secara subyektif merupakan cara untuk menangkap intisari dunia-luar (things). Suatu proses tertentu tersebut disebutnya intuisi yang kreatif (creative intuition).

Berbicara intuisi kreatif seorang dalang, tentu hanya dalang-dalang yang kreatif-lah yang benar-benar dapat kita golongkan ke dalamnya. Untuk membuka paparan selanjutnya digunakan pendekatan fenomenologis yang menempatkan manusia (dalang) sebagai aktor sosial. Pada dasarnya dunia keseharian seorang Dalang dapat dianggap sebagai lokus intersubjektif meminjam istilah Alfred Schutz (1967) yang dijelaskan sebagai teori fenomenologi dengan melihat hal-hal yang kita sadari muncul ke hadapan kita. Cara yang paling mendasar dari pemunculannya itu adalah adanya aliran-aliran pengalaman inderawi yang berkesinambungan yang kita terima melalui panca indera kita. Cara kita mengkontruksikan makna dari arus utama pengalaman yang berupa kumpulan pengetahuan (stock of knoewledge), bukan pengetahuan tentang dunia melainkan segala kegunaan praktis di dunia itu sendiri. Semua aktifitas sosial disusun dan diubah dari interaksi sosial yang diturunkan dari generasi ke generasi melalui proses sosialisasi yang kita lakukan. Asep Sunandar Sunarya sebagai aktor sosial yang memiliki cara pandang, cara bertindak, dan cara berkomunikasinya sebagai Dalang, melalui perspektif komunikasi dicoba digambarkan tentang konsep komunikasi dalang miliknya yang khas.

\section{PEMBAHASAN}

\section{Asep Sunandar Sunarya sebagai Dalang Profesional}

Asep Sunandar Sunarya bersama kelompoknya Giriharja 3 telah berhasil menjadi agen pembaru dalam memasyarakatkan ide-ide barunya pada penonton wayang golek purwa di Jawa Barat, Indonesia, dan Luar Negeri. Asep Sunandar Sunarya telah menunjukan kompetensi komunikasinya sebagai dalang yang komunikatif. Kompetensi komunikasi yang dimilikinya berhasil menarik minat generasi muda menjadi muridnya. Dari studi lapangan yang dilakukan dapat dipahami bahwa para murid ini tertarik karena ide-ide baru yang ditawarkan Asep Sunandar Sunarya. Ide-ide baru sebagaimana dikatakan Rogers dan Shoemaker dalam bukunya Memasyarakatkan Ide-ide Baru (1987) bahwa ide-ide baru biasanya masuk ke dalam sistem sosial melalui anggota yang status sosialnya lebih tinggi dan lebih inovatif. Hal ini mungkin karena agen pembaharu lebih suka berkomunikasi dengan mereka atau mereka itu memang lebih suka mencari inovasi (1987:138-139). Inovasilah yang melatarbelakangi mengapa sebagian kecil dari para pecintanya mau menjadi pewaris aktif gaya mendalang Asep Sunandar Sunarya. Inovasi di dalam perupaan wayang sebagai golek (boneka) yang glamour, indah dan ekspresif. Inovasi di dalam pertunjukan wayang yang menggunakan struktur longgar dan memanfaatkan lelucon serta wejangan menjadi satu kesatuan yang utuh. Inovasi gamelan multi laras (gamelan selap), peralatan panggung yang didukung sistem tata suara dan luas panggung yang besar. Semua inovasi tersebut menjadikan pertunjukan- 
nya tampak megah dan indah, sebagaimana dikemukakan oleh Agus Sachari dalam Estetika Terapan (1989: 40).

\footnotetext{
Manusialah yang menjadikan sesuatu itu indah atau tidak. Dan manusialah yang meyakini sesuatu itu indah atau tidak. Jika di dalam diri kita diyakini adanya emosi, intuisi, rasa, jiwa, keimanan, firasat dan kreativitas, apakah kita yakin bahwa semua itu adalah sumber yang membangun keindahan itu menjadi eksis, ada.
}

Dalam proses membangun keindahan itu, kembali Sachari berpendapat bahwa massa pun memiliki selera yang turut membangun estetika keindahannya menurut mereka. Estetika semacam ini dapat disebut sebagai estetika massa. Estetika massa biasanya cepat berubah dan penuh dinamika, sejalan dengan dinamika sosial dan kebudayaaan. Estetika massa akan membentuk pola tingkah laku estetik yang berkaitan dengan gaya hidup, persepsi masyarakat, konsumsi barang dan kesenian. Adakalanya para seniman berpengaruh besar menggiring masyarakat ke arah pola kesadaran estetik tertentu. Pengaruh itu bisa melalui penyajian karya seni tertentu yang kemudian digandrungi, bisa melalui media informasi, bisa melalui pendidikan, bisa melalui bursa-bursa seni, bahkan bisa pula melalui barang-barang keseharian. Atau bisa pula melalui pola tingkah laku para pemimpin dan pejabat, atau istri-istri pembesar (Sachari, 1989: 48). Melalui jargon "tiada hari tanpa inovasi" dan "miindung ka waktu mibapa ka zaman" memperlihatkan bahwa Asep Sunandar Sunarya memahami estetika wayang juga estetika massa.

Berlangsungnya peristiwa komunikasi di dalam dunia pedalangan wayang golek purwa di Jawa Barat dapat dipahami sebagai kegiatan yang menanjak (rising action) diakibatkan oleh tindakan pembaru yang dilakukan dalang Abah Sunarya sejak tahun 1970. Kemudian dilanjutkan oleh anaknya Ade Kosasih Sunarya yang mulai mematangkan ide-ide baru ayahnya dengan melahirkan tontonan wayang yang memikat penonton. Meskipun hasilnya banyak menuai kritikan, tetapi Ade Kosasih Sunarya terus melakukannya tanpa berhenti. Bahkan dilanjutkan oleh Asep Sunandar Sunarya adiknya yang lebih berani lagi melakukan inovasi-inovasi baru. Maka sejak tahun 1980-an dunia pedalangan wayang golek purwa di Jawa Barat mencapai puncaknya oleh Ade dan Asep. Akhirnya Asep Sunandar Sunarya berhasil menjadi dalang paling populer.

Mengapa Asep Sunandar Sunarya menjadi dalang paling populer? Dari hasil studi lapangan ditemukan fenomena-fenomena yang menunjukan apa saja yang dilakukan Asep Sunandar Sunarya untuk meraih popularitasnya. Berikut ini dapat diidentifikasi empat hal, yaitu: (1) Mengembangkan komunikasi dengan segala lapisan masyarakat; (2) Membuka diri untuk di kritik oleh siapapun; (3) Melakukan inovasi tanpa berhenti dalam pertunjukannya; (4) Mendapatkan penghargaan dari profesinya. Untuk lebih jelas dan rinci dapat dilihat dari tabel di bawah ini.

Memperhatikan tabel ini menunjukkan bahwa Asep Sunandar Sunarya seorang dalang yang professional $^{2}$ di bidangnya serta memiliki kemampuan softskill dan liveskill yang nyata. Kompetensi komunikasi yang dimilikinya tersebut menjadikan dirinya seorang dalang yang komunikatif. Komunikatif berarti memiliki kredibilitas sebagai komunikator yang sadar akan ethos, pathos dan $\log _{0}{ }^{3}$. 


\section{Tabel 1 : Fenomena Asep Sunandar Sunarya menjadi dalang paling populer}

\begin{tabular}{|c|c|c|c|}
\hline $\begin{array}{l}\text { Mengembangkan } \\
\text { Komunikasi Dengan } \\
\text { Segala Lapisan } \\
\text { Masyarakat }\end{array}$ & $\begin{array}{c}\text { Membuka Diri Untuk } \\
\text { Di Kritik Oleh } \\
\text { Siapapun }\end{array}$ & $\begin{array}{c}\text { Melakukan } \\
\text { Inovasi Tanpa } \\
\text { Berhenti Dalam } \\
\text { Pertunjukannya }\end{array}$ & $\begin{array}{c}\text { Menerima } \\
\text { Penghargaan Dari } \\
\text { Profesinya }\end{array}$ \\
\hline $\begin{array}{l}\text { Berkomunikasi de- } \\
\text { ngan para nayaga dan } \\
\text { masyarakat sekitarnya. }\end{array}$ & $\begin{array}{c}\text { Kritik sepedas apapun } \\
\text { diterima sebagai } \\
\text { bagian dari perhatian } \\
\text { penonton. }\end{array}$ & $\begin{array}{l}\text { Semua pergaulan dan } \\
\text { kritikan dimanfaat- } \\
\text { kan untuk menjadi } \\
\text { "sumber" penciptaan } \\
\text { kreativitasnya. }\end{array}$ & $\begin{array}{l}\text { Penghargaan yang } \\
\text { diterima dalam bentuk } \\
\text { fasilitas sarana pertun- } \\
\text { jukan. }\end{array}$ \\
\hline $\begin{array}{l}\text { Berkomunikasi dengan } \\
\text { para petani domba } \\
\text { miliknya dan pecinta } \\
\text { domba di PDHI. }\end{array}$ & $\begin{array}{l}\text { Kritik baginya me- } \\
\text { rupakan "pemacu" } \\
\text { kreativitas bagi per- } \\
\text { tunjukannya. }\end{array}$ & $\begin{array}{l}\text { Inovasi-inovasi yang } \\
\text { dilakukan bertolak } \\
\text { dari jargon yang di- } \\
\text { ciptakannya "tiada } \\
\text { hari tanpa inovasi". }\end{array}$ & $\begin{array}{c}\text { Penghargaan yang } \\
\text { diterima dalam bentuk } \\
\text { penghasilan dari kerja } \\
\text { profesinya. }\end{array}$ \\
\hline $\begin{array}{l}\text { Berkomunikasi de- } \\
\text { ngan para seniman } \\
\text { dan budayawan di } \\
\text { dalam dan di luar } \\
\text { lingkungan dunia } \\
\text { pedalangan wayang } \\
\quad \text { golek purwa. }\end{array}$ & $\begin{array}{l}\text { Kritik yang paling } \\
\text { keras datang dari } \\
\text { para dalang tua di } \\
\text { luar ayahnya, karena } \\
\text { dianggap "merusak" } \\
\text { pakem Pedalangan. }\end{array}$ & $\begin{array}{c}\text { Ide-ide baru yang } \\
\text { dimunculkannya lebih } \\
\text { memiliki “daya tarik } \\
\text { “teatrikalitas terutama } \\
\text { eksplotasi wayang- } \\
\text { wayang Buta (raksasa) } \\
\text { yang bukan tokoh. }\end{array}$ & $\begin{array}{c}\text { Penghargaan yang } \\
\text { diterima dalam bentuk } \\
\text { piagam-piagam peng- } \\
\text { hargaan, baik dari } \\
\text { dalam negeri maupun } \\
\text { luar negeri. }\end{array}$ \\
\hline $\begin{array}{l}\text { Berkomunikasi den- } \\
\text { para pejabat, baik } \\
\text { maupun militer. } \\
\text { tingkat desa } \\
\text { tingkat negara. }\end{array}$ & $\begin{array}{l}\text { Kritik juga datang dari } \\
\text { kalangan seniman } \\
\text { dan budayawan di } \\
\text { luar dunia pedala- } \\
\text { ngan, karena dianggap } \\
\text { "pendangkalan" dan } \\
\text { "vulgar". }\end{array}$ & $\begin{array}{l}\text { Ide-ide baru yang } \\
\text { dimasyarakatkannya } \\
\text { menjadi "memoryafter- } \\
\text { mage" bagi penonton tok } \\
\text { fanatiknya, terutama } \\
\text { di dalam adegan "ban- } \\
\text { yolan panakawan". }\end{array}$ & $\begin{array}{l}\text { Penghargaan yang gan } \\
\text { diterima dalam bentuk sipil } \\
\text { pengakuan menjadi Mulai } \\
\text { koh masyarakat dan sampai } \\
\text { tokoh seniman peda- } \\
\text { langan. }\end{array}$ \\
\hline $\begin{array}{l}\quad \text { Berkomunikasi } \\
\text { dengan para pengu- } \\
\text { saha besar dan kecil, } \\
\text { politikus partai, mulai } \\
\text { dari tingkat ranting- } \\
\quad \text { cabang-pusat. }\end{array}$ & & $\begin{array}{l}\text { Ide-ide baru yang } \\
\text { dikembangkan dalam } \\
\text { menyampaikan pe- } \\
\text { san-pesannya merupa- } \\
\text { kan seni kemas (pack- } \\
\text { age arts) yang jarang } \\
\text { dilakukan dalang lain. }\end{array}$ & $\begin{array}{c}\text { Penghargaan yang } \\
\text { diterimanya ditunju- } \\
\text { kan masyarakat pecin- } \\
\text { ta wayang Indonesia } \\
\text { hanya Asep Sunandar } \\
\text { Sunarya yang dima- } \\
\text { sukan dalam deretan } \\
\text { dalang-dalang terna- } \\
\text { ma di Indonesia. }\end{array}$ \\
\hline $\begin{array}{l}\quad \text { Berkomunikasi } \\
\text { dengan para peneliti } \\
\text { domestik dan luar } \\
\text { negeri, dari kalangan } \\
\text { akademisi maupun } \\
\text { bukan akademisi. }\end{array}$ & & $\begin{array}{l}\text { Meramu lelucon dan } \\
\text { wejangan menjadi } \\
\text { kemasan "pesan" } \\
\text { yang menarik. Lelucon } \\
\text { merupakan "jalan ma- } \\
\text { suk" untuk wejangan. }\end{array}$ & \\
\hline \multicolumn{4}{|l|}{$\begin{array}{l}\text { Berkomunikasi de- } \\
\text { ngan insan pers media } \\
\text { massa: para wartawan } \\
\text { cetak, Televisi dll. }\end{array}$} \\
\hline $\begin{array}{l}\text { Berkomunikasi dengan } \\
\text { kalangan pesantren: } \\
\text { Kiayi, Ustradz, Santri } \\
\text { di berbagai tempat di } \\
\text { Indonesia. }\end{array}$ & & & \\
\hline
\end{tabular}




\section{Konsep Komunikasi Dalang Mandala Wiwaha Asep Sunandar Sunarya}

Asep Sunandar Sunarya sebagai seorang dalang populer karena kreativitas dan "kebintangannya" sampai saat ini, tak diragukan lagi karena memiliki potensi komunikasi yang luar biasa. Asep Sunandar Sunarya sudah mampu menjawab tantangan zamannya, teks dan konteks menjadi "kata sambung" yang selalu melekat di dalam setiap pertunjukannya. Komunikasi kepada penonton selalu dijalin dengan cara-cara yang komunikatif.

Manusia mengkomunikasikan dirinya kepada yang lain, seakan-akan memindahkan diri kepada yang lain. Kita pahami bahwa istilah 'komunikasi' berasal dari kata latin "communicare"; artinya 'memberikan sebagian', atau 'ikut ambil bagian' (Baker, 2000: 146). Komunikasi juga dapat diartikan sebagai "berbagi pengalaman" sampai batas-batas tertentu. Bersifat unik karena dilakukan dengan mempergunakan lambang-lambang, di mana manusia dapat berbagi pengalaman secara tidak langsung dalam memahami pengalaman orang lain. (Tubbs dan Moss, 2001: 4-5).

Lambang-lambang yang dimaksud, bagi komunikasi seorang dalang adalah sejumlah wayang (120 buah golek dengan berbagai karakter, rias busana, warna suara), lakon wayang (Mahabharata dan $R a-$ mayana), gamelan wayang, kawih Sinden, dan lain-lain. Lambang-lambang tersebut dikoordinasikan oleh seorang Dalang. Seorang Dalang sudah seharusnya berbagi pengalaman dan memberi petunjuk melalui pesan-pesan yang disampaikannya, karena memang sudah merupakan tugasnya sebagai komunikator, vokalisator, atau kreator.
Asep Sunandar Sunarya yang telah membuktikan dirinya mewarisi wayang golek purwa dari orang tuanya tanpa berhenti melakukan inovasi dalam pertunjukannya. Inovasi yang dimaksud adalah ide-ide baru yang awalnya merupakan eksperimen di dalam pertunjukannya. Eksperimen yang disajikannya dapat dianggap pula sebagai uji coba untuk penonton, sebagaimana tuturannya:

\begin{abstract}
"Kumargi penonton dianggap mataholang, nya tos kawajiban dalang milari ide-ide anyar supados teu bosenen. Penonton bosen bahaya mengancam, dalang bakal ditinggalkeun penonton. Memang teu ngadadak tapi lalaunan nu nongtona ngorotan, lami-lami sepi panggungan, tungtungna parem. Dalang pangsiun sateuacan waktuna. Kumargi kitu ide-ide anyar ku urang ditawarkeun ka penonton, margi penonton mah hoyong bae aya nu anyar. Ide-ide anyar tiasa ngagali ti mana bae, janten ka urangna oge teu bosen. Batur bosen komo urang. Tah ulah kitu urang mah. Abah ge ka murid-murid sok mapagahan, "batur bosen komo urang" hartina teh urang kudu boga inovasi, sering Abah ngadugikeun "tiada hari tanpa inovasi". Eta cepengan Abah, pami di tarurutan ku murid, mangga bae $e^{4}$.
\end{abstract}

("Karena penonton dianggap mataholang, jadi sudah kewajiban dalang mencari ide-ide baru supaya tidak bosan. Penonton bosan bahaya mengancam, dalang akan ditinggalkan penonton. Memang tidak tibatiba tapi perlahan penonton berkurang, lama kelamaan sepi tak ada panggungan. Dalang pensiun sebelum waktunya. Karena itu ideide baru oleh kita tawarkan ke penonton, sebab penonton itu selalu ingin yang baru. Ide-ide baru bisa menggali darimana saja, jadi kita juga tidak bosan. Orang lain bosan apalagi kita. Nah kita jangan sampai begitu. Saya menasehati murid-murid juga begitu " orang lain bosan apalagi kita" artinya kita harus punya inovasi, sering saya sampaikan "tiada hari tanpa inovasi". Ini pegangan saya kalau diikuti oleh murid-murid ya silahkan saja.")

Kesadaran Asep Sunandar Sunarya terhadap pentingnya penonton menjadikan 
dirinya memberi banyak untuk berbagi dengan penonton. Sebenarnya ia membangun selera penonton terhadap gaya mendalang yang ditawarkannya. Pada sisi lain, ia menawarkan satu konsep komunikasi mendalang untuk sampai pada tahap seorang dalang dapat melayani penontonnya, yaitu mandala wiwaha.

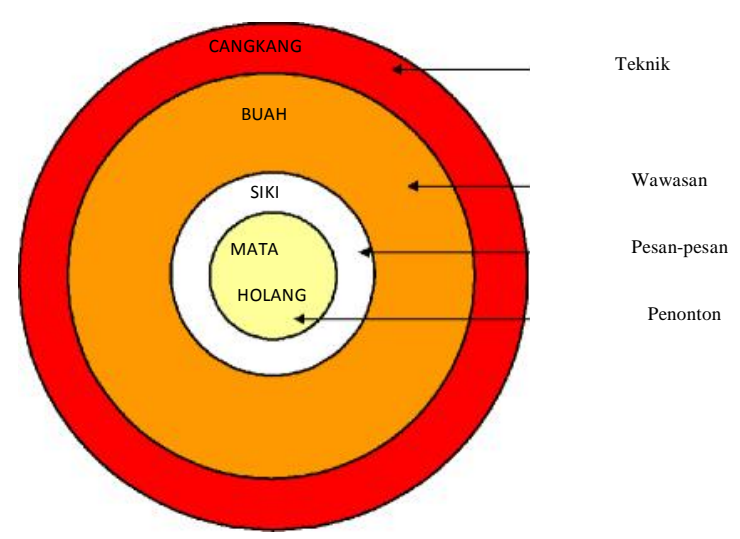

Konsep Mandala Wiwaha disampaikan


sebuah penawaran untuk para dalang agar memiliki kompetensi komunikasi
penawaran untuk para dalang agar memiliki kompetensi komunikasi yang jelas, baik dari sisi teknik maupun dari sisi pesan, juga dari sisi penonton. Konsep Mandala wiwaha sebagaimana digambarkan di atas, memperlihatkan Cangkang artinya penguasaan teknik ngawayang. Buah artinya pengasaan wawasan. Siki artinya penegasaan pesan-pesan (nilai-nilai moral dan kemanusiaan). Mataholang artinya penguasaan penonton.

Penonton di dalam konsep Mandala Wiwaha menjadi sangat penting karena tanpa penonton pertunjukan wayang tak ada artinya. Konsep Mandala Wiwaha merupakan konsep yang dapat disebut sebagai Ajaran Asep Sunandar Sunarya di dalam melakukan profesinya sebagai dalang. Dia memahami benar dunia profesinya dengan segala konsekuensinya. Salah satu yang ditakutinya ternyata adalah ditinggalkan penonton. Berikut penuturannya:
"Salah sahiji kasieun Abah mah ditinggalkeun penongton, taya hartina lamun dalang ditinggalkeun penongtona, kacida wirangna. Matak kudu kreatif, inovatif, komunikatif. Carana nya dina wayangna kudu alus jeung payus, gamelana kudu nyurup jeung guyub, sindena kudu pantes jeung rancinges, manggungkeunana kudu hade jeung rame. Sabab lamun rame geus pati panongton kahibur, gumbira. Lamun jalma hatena keur gumbira, tah didinya ku urang asupkeun papagah geus pasti nyerep kana mamarasna ${ }^{5} . "$

("Salah satu ketakutan saya ditinggalkan penonton, tak ada artinya kalau dalang ditinggalkan penontonnya, sangat memalukan. Karena itu harus kreatif, inovatif, komunikatif. Caranya dalam wayang harus bagus dan pantas, gamelannya harus tepat dan kompak, pesindennya harus patut dan tangkas, mempertunjukannya harus bagus dan meriah. Sebab kalau meriah sudah pasti penonton terhibur, gembira. Kalau orang hatinya sedang gembira, nah di situ oleh kita masukan nasehat sudah pasti meresap ke dalam hatinya yang paling dalam.")

Kesadaran terhadap pentingnya penonton menjadi kesatuan yang tak dapat dipisahkan dari tontonan yang ia lakukan. Jadi pertunjukan tidak dapat disebut pertunjukan kalau tidak ada penontonnya, sebab itu artinya tidak pernah terjadi hubungan resiprositas (timbal balik) antara tontonan dan penonton. Tontonan berisi tuntunan melalui makna pesan di dalamnya, penonton merespon makna pesan tersebut sebagai tuntunan. Meminjam pendapat Muji Sutrisno (1993: 36) tentang wayang yang menjadi tontonan sekaligus tuntunan:

Tidak dapat disangkal bahwa wayang di satu pihak merupakan seni pertunjukan. Dari sisi ini saja dengan mudah kita mengerti aspeknya sebagai tontonan. Dengan tontonan, maka publik berhak menemukan segi "leisure"-nya, sisi eksostisnya tak hanya sedap di mata, enak di telinga tetapi pula lucu lawak menyegarkan yang diharap mampu mengenyahkan seluruh kepenatan 
hidup rutin. Tetapi wayang mempunyai sisi simboliknya, mistiknya, pesannya, ajaran dan tuntunannya.

Komunikasi dalang dengan penonton terjadi karena adanya timbal balik di antara keduanya sebagai proyeksi yang mengarahkan kepada pemahaman bahwa pertunjukan dan penonton tidak bisa dipisahkan. Pemahaman seperti ini dapat disebut sebagai komunikasi dalang.

Bentuk komunikasi dalang seperti itu sesungguhnya telah diperlihatkan oleh $d i$ nasti Sunarya, sejak perintisan oleh Abah Sunarya yang membawakan wayang dengan cara dan gaya mendalangnya yang khas berbeda dengan dalang di zamannya. Misalnya dalam murwa yang dibawakan bernuansa Islami. Hal ini dilakukannya semata-mata karena keinginannya untuk berkomunikasi dengan masyarakat penonton. Abah Sunarya menyadari benar bahwa mayoritas penontonnya beragama Islam dan menyadari pula bahwa seringkali para Ulama atau Kiayi tertentu pobia terhadap wayang yang mereka anggap sebagai "warisan" agama Hindu, bahkan ada juga yang mengharamkan wayang.

Bertolak dari alasan seperti itulah Abah Sunarya mencoba menafsirkan murwa yang menggunakan bahasa Kawi yang sulit dimengerti diganti dengan bahasa Sunda yang mudah dimengerti karena mayoritas penontonnya orang Sunda. Kesadaran terhadap bahasa lokal menjadi penanda Abah Sunarya bahwa dalang harus dapat menjalin komunikasi dengan penontonnya. Karena itu setiap membuka pertunjukan, Abah Sunarya selalu memulainya dengan murwa Islami. Murwa dapat dianggap sebagai puisi lama dengan bahasa Kawi, memiliki tujuan sebagai doa. Maka Abah Sunarya menggan- tinya dengan terjemahan Basmalah yang dikembangkannya menjadi lebih luas dan mendalam. Spiritualitaslah yang diinginkan Abah Sunarya dalam membuka pertunjukan wayangnya. Hal ini menunjukan hadirnya pengalaman dan kesadaran terhadap lingkungan sekitarnya, dalam hal ini penonton.

Agama-agama tradisional tentu saja menjelmakan bentuk-bentuk pengalaman ini, tetapi sama sekali tidak menghabiskannya. Semua seni yang besar dalam penciptaan dan penerimaanya adalah suatu ungkapan yang hidup akan spiritualitas manusia. Ketakziman dan keharuan, cinta dan pemujaan memperlihatkan contoh bentuk-bentuk spiritualitas yang berbeda. Perenungan pada sepotong puisi yang bagus adalah suatu pengalaman spiritual par excellence (yang tiada taranya) ${ }^{6}$.

Kebiasaan ini menjadi salah satu ciri Abah Sunarya memposisikan dirinya sebagai dalang yang benar-benar mendudukan penonton menjadi mitra komunikasinya. Hal ini dilakukan untuk menjalankan khatarsis (pencerahan batin) yang dialaminya, sehingga selalu memulai dengan murwa Islami. Sejak itu mulailah murwa tersebut menjadi tradisi pembuka di dalam setiap pertunjukan wayang golek purwa gaya Giriharja.

Perintisan gaya berkomunikasi dalang yang sadar akan penonton sebagai mitra komunikasinya tampak benar di kalangan dalang dari dinasti Sunarya. Salah satu yang tampak secara kasat mata berduyun-duyunnya penonton ke dalam setiap pertunjukan wayang golek purwa gaya Giriharja. Dalang sebagai komunikator memiliki apa yang disebut faktor atraktif (source of attractiveness) dan faktor kepercayaan (source of credibility) ${ }^{7}$. 
Pertunjukan wayang yang seperti ini yang memiliki kemungkinan menjadi impian setiap dalang. Namun peristiwa komunikasi seperti itu tidak mudah tercapai kalau dalangnya egois hanya mencari kepuasan untuk dirinya sendiri tanpa mempertimbangkan mendalang untuk penonton.

Dalam kaitan itu, pandangan Asep Sunandar Sunarya membuka cakrawala kita di dalam memahami komunikasi dalang.

\footnotetext{
"Numutkeun Abah mah lamun aya dalang nongtoyod bae ngawayang, ngeunah jang sorangan. Teu malire kana kahayang nu nongton, eta dalang sanes dalang sajati tapi dalang teu uni. Sabab duka saha guruna lamun aya dalang petana kawas kitu, justru ari dalang mah apan tukang mere pitunjuk, jadi dalang mah kudu bisa neuleuman hate nu nongton. Saha nu nongton urang, di mana, hajatan hiburan atawa hajatan ruatan, pokona kudu apal saha panongton urang." 8
}

("Menurut saya kalau ada dalang yang asyik sendiri dalam ngawayang, enak sendiri untuk dirinya sendiri. Tidak memperhatikan pada keuinginan penonton, itu dalang bukan dalang sejati tetapi dalang yang tidak bener. Sebab tidak tahu siapa gurunya kalau ada dalang kelakukannya seperti itu, justru dalang itu kan tugasnya memberi petunjuk, jadi dalang itu harus bisa merasakan hati penonton. Siapa penonton kita, di mana, hajatan hiburan atau hajatan ruatan, pokoknya harus hafal siapa penonton kita.")

Kesadaran Asep Sunandar Sunarya terhadap pentingnya penonton tampaknya merupakan hasil pengalaman di berbagai tempat pertunjukan. Belajar dan bekerja menjadi menyatu dalam kegiatannya sehari-hari. Karena itu untuk menambah bobot ngawayang dan ngadalang-nya tak segan-segan menjalankan komunikasi insani dengan berbagai lapisan masyarakat. Konsep yang dipakainya adalah depe-depe jeung handap asor (hormat kepada setiap orang dan tidak sombong), melalui kon- sep tersebut banyak peluang datang, di antaranya peluang bertambahnya wawasan serta tawaran panggungan. Hal ini menjadi sangat berarti bagi dirinya, karena dirinya merasa memiliki keterbatasan di dalam hal pendidikan formal.

Jaringan pergaulan yang dilakukannya tak berhenti di dalam negeri tetapi juga di luar negeri, karena itu sebenarnya komunikasi dalang yang dilakukannya tak terbatas. Kapan saja dan di mana saja, seorang dalang seperti dirinya merasa tetap perlu belajar dari lingkungan dan merasa tak menjadi masalah terhadap tempat pertunjukan. Sebagai salah satu contoh, ketika Asep Sunandar Sunarya melakukan pertunjukan keliling di negara Inggris. Salah satu pengalamannya adalah melakukan pertunjukan wayang golek di sebuah Gereja. Para penonton antusias melihat pertunjukannya, tua dan muda bahkan anak-anak pun hadir. Suasana yang berbeda karena memasuki Gereja merupakan pengalaman baru dalam seumur hidupnya, menambah kesadaran untuk memilih lakon yang menyadarkan manusia untuk tidak bersikap sombong. Maka Asep Sunandar Sunarya mempertunjukan lakon Dursasana Pejah, sebuah lakon carangan yang mengisahkan kematian Dursasana9. Alasan lakon tersebut dipertunjukan, Asep Sunandar Sunarya mengatakannya:

\footnotetext{
"Dursasana boga sifat takabur, sewenang-wenang, gede hulu, ngaremehkeun batur, resep ngahina batur. Tah kalakuan kitu anu kudu dibasmi. Nya dibasmina ku Bima anu jadi lambang kawani kusabab bener, satia kana jangji, jeung jujur. Urang terang, di unggal nagara oge loba jalma anu kalakuanana siga Dursasana, tah kusabab kitu ku Abah harita dipintonkeun. Beres pertunjukan penonton jadi panasaran kana wayang golek Abah. Atuh wayang oge diarome, maruji kana wayang urang, tungtungna aya oge anu meser wayang." 10
} 
("Dursasana memiliki sifat takabur, sewenang-wenang, besar kepala, meremehkan orang lain, senang menghina orang lain. Prilaku seperti itu yang harus dibasmi. Dibasminya oleh Bima yang menjadi lambang keberanian karena benar, setia pada janji, serta jujur. Kita tahu, di setiap negara juga banyak prilaku seperti Dursasana, karena itu waktu itu oleh saya dipertunjukkan. Pertunjukan selesai penonton menjadi penasaran pada wayang golek saya. Wayang juga dipegang dan dimainkan, memuji kepada wayang kita, akhirnya ada juga yang membeli.")

Adanya unsur kesengajaan di dalam memilih peristiwa dramatik dalam lakon Dursasana Pejah meniru Abah Sunarya ayahnya, ketika mempertunjukan lakon carangan Tangkal Rahayu Ning Rat di Swedia tahun 1985. Bahwa orang Barat (Inggris) menyenangi konflik dan heroik. Konflik biasanya terjadi antara tokoh Protagonis dan Antagonis. Di dalam lakon Dursasana Pejah, tokoh Bima sebagai Protagonis dan tokoh Dursasana sebagai Antagonis ${ }^{11}$. Di samping konflik dan heroik, orang Inggris menyenangi komedi. Karena itu Asep Sunandar Sunarya mengemas lelucon Panakawan menjadi lebih menarik, baik dengan bahasa lisan (bahasa Sunda-Indonesia-Inggris) maupun dengan bahasa tubuh (sabet) yang atraktif dan teatrikal.

"Bahasa nu diangge campur-campur bae, Sunda-Indonesia-Inggris oge. Inggrisna oge anu gampang-gampang bae. Siga what your names ? Where do you live? kitu. Tapi biasa diheureuykeun ku si Cepot mah. Kadituna mah biasa gelut Buta, pokona rame!"12

(Bahasa yang dipakai campuran saja, Sunda-Indonesia-Inggris. Inggrisnya juga yang gampang saja. Seperti Siapa namamu? Di mana tempat tinggalmu? begitu. Tetapi biasa dipermainkan oleh Si Cepot. Seterusnya biasa Buta berkelahi, pokoknya seru!")
Lakon carangan merupakan unggulan Giriharja, tetapi lakon carangan bukan monopoli Giriharja. Lakon carangan merupakan bagian yang tak terpisahkan dari komunikasi seorang dalang dewasa ini. Tidak terbatas pada wayang golek saja, tetapi Wayang Kulit Jawa maupun Wayang Kulit Bali. Sebagaimana pendapat I Wayan Dibya seorang guru besar seni pertunjukan Bali:

Penggunaan lakon-lakon carangan juga merupakan sebuah fenomena baru. Hal ini berbeda dengan dalang-dalang tua yang pada umumnya menampilkan lakon-lakon pokok. Tampaknya, lakon carangan ini memberikan ruang yang cukup terbuka bagi para dalang untuk memasukan ide-ide baru yang lebih aktual, agar pertunjukannya lebih menarik. Ada juga yang mengatakan bahwa pementasan lakon carangan lebih mudah dari pada lakon pokok. ${ }^{13}$

Wayang golek purwa gaya Giriharja memang telah membuka mata kita mencoba mengerti hakekat peristiwa komunikasi. Peristiwa komunikasi berlangsung dalam interaksi timbal balik, antara tontonan dan penonton. Tontonannya bisa saja asing bagi penonton, misalnya bagi penonton orang Inggris yang menonton wayang golek purwa gaya Asep Sunandar Sunarya. Penonton tidak mengerti bahasa Sunda yang dituturkan dalang, tetapi penonton dapat menyaksikan teatrikalitas wayang golek sebagai boneka, bahasa non verbal yang dipergunakan lebih dapat memukau mata karena atraktif dan dinamis. Atraktif dapat diartikan memiliki daya tarik yang menyenangkan secara langsung sehingga menarik banyak penonton. Dinamis dapat diartikan memiliki semangat dan dan tenaga sehingga cepat bergerak dan mudah menyesuaikan diri dengan keadaan. Pertunjukan lebih banyak menggunakan 
permainan sabet karena mampu mengundang reaksi spontan penonton. Wayang Buta dan wayang Panakawan gaya Giriharja telah menjadi boneka-boneka hidup di tangan Asep Sunandar Sunarya. Adegan atraksi perang antara wayang Buta dengan Cepot seringkali dibuat dengan teknik meniru film kartun, seperti gerak lambat (slow motion), gerak cepat (speed motion), gerak balik (reverse).

Di samping itu wayang golek sebagai boneka yang disebut gaya Giriharjan memiliki bentuk dan rupa yang dibuat glamour dan indah. Penonton asing sangat menyukainya, terutama anak-anak. Asep Sunandar Sunarya menjadikan sebagai benda yang dapat dibeli dengan harga yang pantas sesuai dengan kerumitan di dalam membuatnya. ${ }^{14}$

Pengalaman melakukan pertunjukan di Mancanegara menjadikan Asep Sunandar Sunarya memiliki wawasan kesenian yang baru. Bahwa kesenian dapat menjembatani perbedaan-perbedaan antar bangsa. Melalui kesenian dirinya dapat memberikan kontribusi yang berarti bagi bangsa dan negara. Berikut penuturan Asep Sunandar Sunarya tentang pengalaman pertunjukan di Mancanegara, bahwa kesenian dapat menjadi media komunikasi.

"Tetela kasenian urang teh boga ajen ti bangsa sejen. Utamana wayang golek anu ku Abah dijalankeun. Wayang golek teh seni karuhun anu ku urang kudu dipusti-pusti tapi lain teu beunang dirobah, malah kudu diolah sangkan penonton di mana bae, bangsa naon bae resepeun kana wayang. Batur mah ningali wayang teh siga ningali barang antik, komo barang dipagelarkeun, karasa atuh sambutanana. Penonton resep komo Abah."15

("Ternyata kesenian kita itu dihargai oleh bangsa lain. Utamanya wayang golek yang saya jalani. Wayang golek itu seni leluhur yang oleh kita harus dihargai tetapi bukan tidak boleh dirubah, bahkan harus diolah supaya penonton di mana saja, bangsa apa saja menyenangi wayang. Orang lain melihat wayang seperti melihat barang antik, apalagi ketika dipertunjukan, terasa sekali responnya. Penonton senang apalagi saya.")

Peristiwa komunikasi yang diperlihatkan Asep Sunandar Sunarya melalui gaya mendalangnya tersebut memiliki peluang sebagai contoh bahwa komunikasi dalang itu ada dan penting untuk dipahami. Komunikasi Dalang Asep Sunandar Sunarya adalah suatu keniscayaan yang tak mungkin diabaikan, karena konsep Mandala Wiwaha merupakan ajaran hidup jika ingin menjadi dalang profesional. Dalang profesional adalah impian setiap generasi dalang sejak dulu sampai sekarang. Jargon "Miindung ka waktu Mibapa ka zaman" merupakan bagian yang tak terpisahkan dari komunikasi dalang Asep Sunandar Sunarya.

\section{PENUTUP}

Pengakuan bangsa lain pada Asep Sunandar Sunarya terbukti sudah. Asep Sunandar Sunarya sebagai dalang profesional yang "kebintangannnya" diakui itu menjadikan dirinya sangat peka terhadap penonton. Penonton dapat dilayaninya sebagaimana harapan masyarakat mereka menonton, bagi penonton yang butuh hiburan hanya cukup diberi ngawayang (berbagai teknik-tontonan) saja. Sedangkan bagi penonton yang bukan hanya buth hiburan tetapi juga butuh nilai-nilai moral dan kemanusiaan yang disajikan melalui pesan-pesan tokoh wayang yang dimainkannya kemudian diberi ngadalang (isi-tuntunan). Komunikasi dalang yang dipilihnya intim dan komunikatif, karena Asep Sunandar Sunarya sadar bahwa pe- 
nonton adalah mataholang. Asep Sunandar

Sunarya telah menanamkan benih-benih nilai tuntunan hidup melalui konsep Mandala Wiwaha kepada penontonnya. Konsep Mandala Wiwaha dapat dikatakan sebagai ajaran yang diwariskan Asep Sunandar Sunarya kepada para muridnya. Konsep Mandala Wiwaha adalah konsep penguasaan teknik, wawasan, pesan-pesan dan penonton. Para muridnya pun memahami benar bahwa konsep Mandala Wiwaha adalah sangat penting apabila dirinya ingin menjadi dalang profesional, sebagaimana gurunya.

\section{CATATAN AKHIR}

${ }^{1}$ Beberapa dalang dewasa ini telah melakukan dinamisasi pertunjukannya sebagai pembaru dunia pedalangan di Indonesia, seperti Enthus Sukmono (Wayang Kulit Jawa), Made Sidia (Wayang Kulit Bali), Lalu Nasib (Wayang Kulit Lombok), dan Asep Sunandar Sunarya (Wayang golek Purwa Sunda).

2 Profesional artinya orang yang mengerjakan sesuatu sesuatu (olah raga, lukis-melukis, musik, dll) bukan hanya karena dorongan rasa senang, tapi juga karena menempatkan pekerjaan, jabatan atau profesi yang ia emban sebagai sumber mata pencaharian; bersangkutan dengan profesi; memerlukan kepandaian khusus untuk menjalankannya; mengharuskan adanya pembayaran untuk melakukannya (lawan amatir) (Dagun, 2005: 893). Meskipun seorang professional, tetapi di dalam realitasnya Asep Sunandar Sunarya menerima "pembayaran" tidak hanya uang tetapi "hadiah" tertentu yang bersifat barang., misalnya kendaraan roda empat dari tokoh masyarakat tertentu.

${ }^{3}$ Ethos ialah kekuatan yang dimiliki pembicara dari karakter pribadinya, sehingga ucapan-ucapannya dapat dipercaya. Pathos ialah kekuatan yang dimiliki seorang pembicara dalam mengendalikan emosi pendengarnya, sedangkan logos ialah kekuatan yang dimiliki komunikator melalui argumentasinya. (Cangara, 2000: 96). Ketiga istilah ini disampaikan oleh filsuf Yunani terkenal yaitu Aristoteles.
${ }^{4}$ Wawancara dengan Asep Sunandar Sunarya, Jelekong Kabupaten Bandung 29 Mei 2011. Mataholang merupakan bibit akar dan pucuk yang terdapat dalam biji tanaman. Mata holang adalah penonton sebagaimana terdapat dalam konsep Mandala Wiwaha Asep Sunandar Sunarya.

${ }^{5}$ Wawancara, Asep Sunandar Sunarya, Jelekong Kabupaten Bandung, waktu dan tempat yang sama.

${ }^{6}$ Lihat Skolimowski, Henryk, Filsafat Lingkungan: Merancang Taktik Baru untuk Menjalani Kehidupan, Yogyakarta: Bentang, 2004, hal 48.

${ }^{7}$ Lebih rinci, lihat Santoso Sastropoetro, Pendapat Publik, Pendapat Umum, dan Pendapat Khalayak dalam Komunikasi Sosial, Bandung: PT Remaja Rosda Karya, 1970, hal 16.

8 Wawancara dengan Asep Sunandar Sunarya, waktu dan tempat yang sama.

${ }^{9}$ Lakon Dursasana Pejah, menceritakan kematian Dursasana dalam perang Bharatayudha oleh Bima dalam keadaan sangat menyedihkan. Dadanya dibelah dengan kuku Pancanaka. Darah yang menyebur ditampung Bima untuk memenuhi sumpah Dewi Drupadi, yang tidak akan menggelung rambut sebelum keramas dengan darah Dursasana. Anggota tubuh dan kepala Dursasana hancur tak berbentuk, dihantam gada Rujakpolo. (lihat lebih rinci: Herus S Sudjarwo Dkk, Rupa dan Karakter Wayang Purwa, 2010: 646). Lakon-lakon yang diakhiri dengan kata Pejah, biasanya melakonkan matinya pihak yang jahat dan keburukan, misalnya, Dursasana Pejah, Aswatama Pejah. Sementara lakon-lakon yang diakhiri dengan kata Gugur, biasanya melakon matinya pihak yang baik dan kebaikan., Kumbakarna Gugur, Bisma Gugur.

10 Wawancara, Asep Sunandar Sunarya, waktu dan tempat yang sama.

11 Protagonis adalah tokoh yang membawakan moral cerita (kebaikan), Antagonis adalah tokoh yang melawan moral cerita (keburukan). Simak lakon-lakon drama karya Skahespeare, seorang pengarang besar Inggris klasik, di mana konflik antara kebaikan dan keburukan menjadi pilihannya dan disuguhkan dengan puitis dan dramatis. Seperti King Lear, Hamlet, Rome and Juliet.

${ }^{12}$ Wawancara, Asep Sunandar Sunarya, tempat dan waktu yang sama. 
13 Lihat artikel I Wayan Dibya, Wajah Wayang Kulit bali dewasa ini, dalam Philips Yampolsky (ed) Perjalanan Kesenian Indonesia Sejak Kemerdekaan: Perubahan dalam Pelaksanaan, Isi, dan Profesi, Jakarta: PT Equinox Publishing Indonesia, 2006, hal 104.

14 Wayang Buta dan wayang Panakawan, terutama Cepot, Dawala, Gareng membuatnya lebih mudah karena tidak banyak memiliki kerumitan di dalam motiv ukirannya, sedangkan wayang Pandawa, Kurawa, Raja Raksasa memiliki tingkat kerumitan motif ukiran tertentu, terutama di dalam ukiran mahkota dan rambut.

${ }^{15}$ Wawancara dengan Asep Sunandar Sunarya, waktu dan tempat yang sama.

\section{DAFTAR PUSTAKA}

Bakker, Anton.

2000 "Antropologi Metafisik", Yogyakarta: Kanisius.

Boelaars, Y.

1984 “Kepribadian Indonesia Modern: Suatu Penelitian Antropologi Budaya", Jakarta: PT Gramedia.

Cangara, Hafied.

2000 "Pengantar Ilmu Komunikasi", Jakarta: PT Raja Grafindo Persada.

Rogers, Everett M. dan F. Floyd Shoemaker. 1987 "Memasyarakatkan Ide-Ide Baru", Surabaya: Usaha Nasional.

Sachari, Agus.

1989 "Estetika Terapan", Bandung: Nova.

Sastropoetro, Santoso.

1990 "Pendapat Publik, Pendapat Umum, dan Pendapat Khalayak dalam Komunikasi Sosial", Bandung: PT Remaja Rosdakarya.
Schutz, Alfred.

1967 "The Phenomenology of the social world", translated by George Walsh anda Frederick Lehnert George Walsh, Evanston-Illionis: Northwestern University press.

Skolimowski, Henryk.

2004 "Filsafat Lingkungan", Yogyakarta: Bentang.

Solichin (ed).

2003 "Wayang: Karya Agung Budaya Dunia", Jakarta: Senawangi.

Sudjarwo, Heru S. Dkk.

2010 "Rupa dan Karakter Wayang Pur$w a^{\prime \prime}$, Jakarta: Kakilangit Kencana.

Tabrani, Primadi.

2006 "Kreativitas \& Humanitas: Sebuah Studi Tentang Peranan Kreativitas Dalam Perikehidupan Manusia", Bandung: Jalasutra.

Tubbs, Stewart L dan Sylvia Moss.

2001 "Human Communication: Prinsip Prinsip Dasar", Pengantar Deddy Mulyana, Bandung: Rosda.

Yampolsky, Philip. (ed).

2006 "Perjalanan Kesenian Indonesia Sejak Kemerdekaan: Perubahan dalam Pelaksanaan, Isi, dan Profe$s i^{\prime \prime}$, Jakarta-Singapore: Equinox Publishing. 